\section{Tomasz Bednarek}

Uniwersytet im. Adama Mickiewicza w Poznaniu tomaszbednarek1003@gmail.com

ORCID: 0000-0001-7077-2944

DOI: http://dx.doi.org/10.12775/BPTh.2020.011

\section{Biblica}

et

Patristica

Thoruniensia

13 (2020) 3: 263-276

ISSN (print) 1689-5150

ISSN (online) 2450-7059

\title{
Alegoryczna interpretacja historii Abrahama. Analiza III, IV i VI homilii o Księdze Rodzaju Orygenesa*
}

\section{Allegorical Interpretation of Abraham's Story. Origen's Homilies III, IV and VI on Genesis}

\begin{abstract}
Streszczenie. Orygenes był jednym z najważniejszych myślicieli wczesnego chrześcijaństwa. W swoich pismach odnoszących się do Starego i Nowego Testamentu bardzo często korzystał z interpretacji alegorycznej. Celem artykułu jest analiza III, IV i VI homilii o Księdze Rodzaju Orygenesa. Interpretacja alegoryczna jest dla Orygenesa problemem zarówno hermeneutycznym, jak i filozoficznym. Sposób interpretowania historii Abrahama przez Orygenesa został tu porównany z utworami innych autorów judeohellenistycznych i chrześcijańskich, głównie Filona. Proponowane przez Orygenesa ujęcie historii Abrahama ma na celu obronę chrześcijaństwa przed zarzutami wystosowanymi przez pogan i żydów.
\end{abstract}

\begin{abstract}
Origen was one of the most important thinkers of early Christianity. In his works on the Old and New Testament, he frequently employed allegorical interpretation. The purpose of this article is to analyze Origen's Homilies III, IV and VI on Genesis. Allegorical interpretation is for Origen both a hermeneutical and a philosophical problem. Origen's manner of interpreting Abraham's story is compared here with the works of other Judeo-Hellenistic and Christian authors, Philo in particular. Origen's account of Abraham's story aims to defend Christianity against the charges raised by both pagans and Jews.
\end{abstract}

Słowa kluczowe: Orygenes; Filon z Aleksandrii; interpretacja alegoryczna; alegoria; egzegeza.

Keywords: Origen; Philo of Alexandria; allegorical interpretation; allegory; exegesis.

Niniejsza praca powstała w ramach projektu badawczego nr 2017/25/B/HS1/00559 finansowanego przez Narodowe Centrum Nauki. W tym miejscu pragnę podziękować kierownikowi projektu, prof. Mikołajowi Domaradzkiemu, a także anonimowym recenzentom za cenne uwagi i wskazówki. 


\section{Wstęp}

Celem niniejszego artykułu jest analiza sposobu uprawiania interpretacji alegorycznej przez Orygenesa. Specyfikę podejścia Orygenesa doskonale ilustruje jego ujęcie historii Abrahama, które przedstawione zostało w trzech pięknych homiliach o Księdze Rodzaju: III, IV i VI (warto w tym miejscu podkreślić, że homilia III jest pierwszą z homilii poświęconych Abrahamowi, podczas gdy homilia $\mathrm{V}$ traktuje o postaci Lota). Analiza homilii, w których Orygenes objaśnia historię Abrahama, umożliwi mi pokazanie, że interpretacja alegoryczna Orygenesa ma charakter zdecydowanie apologetyczny: we wspomnianych homiliach głównym celem Orygenesa jest $\mathrm{z}$ jednej strony niwelowanie tych fragmentów przekazu biblijnego, które czytelnikowi greckiemu wydawać się mogły oburzające lub śmieszne (apologia wobec pogan), a z drugiej dowiedzenie spójności Starego i Nowego Testamentu, ukazane przez interpretację prefiguracyjną w duchu chrystologicznym (apologia wobec wyznawców judaizmu). Dzięki apologetycznej interpretacji alegorycznej Orygenes łączyć mógł ze sobą zasadniczo odmienne przekazy kulturowe: filozofię Greków i religię Objawienia.

Niniejszy artykuł jest, o ile mi wiadomo, pierwszą w naszym kraju próbą całościowego omówienia alegorycznej interpretacji postaci Abrahama przedstawionej w wyżej wymienionych homiliach Orygenesa. Homilie Orygenesa, ze względu na pewne cechy, o których będzie poniżej mowa, są rzadziej analizowane pod kątem zastosowania interpretacji alegorycznej niż jego komentarze biblijne ${ }^{1}$.

1 Odnośnie do prac analizujących homilie Orygenesa por. T. Łuczak, Funkcje symbolicznej interpretacji Pentateuchu w homiliach Orygenesa; M. Spyra, Elementy teologii chrzcielnej w czwartej i piątej homilii Orygenesa do Księgi Jozuego; J. Słomka, Oczyszczenie z grzechu w homiliach Orygenesa o Księdze Kapłańskiej; J. Słomka, Orygenes o kapłaństwie $i$ Eucharystii w homiliach o Księdze Kapłańskiej; P. Klimek, Powołanie Jeremiasza (Jr 1,4-10) w „Pierwszej homilii o Księdze Jeremiasza” Orygenesa; K. Bardski, Intencja tekstu a sens ponaddosłowny. Uwagi na marginesie artykułu ks. Piotra Klimka pt. Powołanie Jeremiasza (Jr 1,4-10) w „Pierwszej Homilii o Księdze Jeremiasza” Orygenesa; A.-Ch. Jacobsen, Allegorical Interpretation of Geography in Origen's Homilies on the Book of Joshua. Prace te jednak nie dotyczą bezpośrednio alegorycznej interpretacji postaci Abrahama w homiliach o Księdze Rodzaju. 


\section{Postać Abrahama w Torze}

Postać Abrahama i jego potomków stanowi treść drugiej części Księgi Rodzaju (rozdziały 12-50). Sam Abraham jest bohaterem rozdziałów 12-24. Przyjmując założenia metody historyczno-krytycznej, badającej tekst Starego Testamentu z perspektywy diachronicznej, historia Abrahama, z którą mamy do czynienia w Księdze Rodzaju, jest wynikiem połączenia kilku źródeł oraz wieloetapowej redakcji, która zakończyła się $\mathrm{w}$ trakcie tak zwanej niewoli babilońskiej (586-538 przed Chrystusem) lub krótko po niej. Konsekwencją takiego sposobu powstawania Księgi Rodzaju są rozbieżności w sposobie narracji i rozmaite niekonsekwencje.

Dosłownie rozumiana historia Abrahama daje szerokie możliwości alegorycznej interpretacji. Dla czytelników pochodzących ze świata grecko-rzymskiego wiele jej elementów mogło wydać się niezrozumiałych, śmiesznych lub zgoła gorszących. Biblijna opowieść o losach patriarchy Abrahama zawiera bowiem treści kulturowo niezrozumiałe (nakaz obrzezania), tajemnicze (zmiana imienia Abrama i Saraj na Abraham i Sara), przesycone antropomorfizmami (wizyta Boga i Jego aniołów w namiocie Abrahama), a także gorszące (tu należy wymienić historię, która przez wieki stanowiła i wciąż stanowi temat dla refleksji teologicznej i filozoficznej: nakaz ofiarowania Bogu jedynego syna, Izaaka²).

\section{Orygenes. Metoda interpretacji Pisma Świętego. Homilie Orygenesa o Księdze Rodzaju}

Orygenes (ok. 184-253 po Chrystusie) należy do najbardziej znaczących myślicieli wczesnego chrześcijaństwa. Wywarł on niezaprzeczalny wpływ na sposób interpretacji Pisma Świętego w Aleksandrii. W skład jego bogatej spuścizny wchodzą utwory apologetyczne (Przeciwko Celsusowi), filozoficzne (O zasadach) i przede wszystkim egzegetyczne (komentarze i homilie dotyczące rozmaitych ksiąg biblijnych).

Orygenes przemyśleniom dotyczącym interpretacji Pisma Świętego poświęcił czwartą księgę dzieła $O$ zasadach. Aleksandryjski teolog niezwykle krytycznie odnosił się do praktyki poprzestawania jedynie na sensie dosłownym Pisma, choć nie wątpił w natchniony sens Starego i Nowego Testamentu - przeciwnie, zaciekle polemizował on ze stanowiskiem marcjonistów, odrzucających

2 Odnośnie do refleksji filozoficznej warto tu wymienić chociażby Bojaźń i drżenie Sørena Kierkegaarda, por. S. Kierkegaard, Bojaźń i drżenie. Choroba na śmierć, s. 3-137. 
Stary Testament. Można powiedzieć, że to właśnie interpretacja alegoryczna jest narzędziem służącym do obrony Starego Testamentu w polemice z marcjonistami. Choć, jak zauważa M. Simonetti, rozmaite elementy interpretacji alegorycznej obecnej u Orygenesa występowały już u wcześniejszych autorów z Aleksandrii, to jednak on sam także wniósł oryginalny wkład do tej praktyki interpretowania tekstu sakralnego (m.in. podjęcie próby interpretacji alegorycznej całego Pisma, znaczące usprawnienie elementów filologicznych) ${ }^{3}$.

Homilie o Księdze Rodzaju ${ }^{4}$ powstały w czasie pracy Orygenesa w Cezarei Palestyńskiej w latach 245-250. Będąc już w podeszłym wieku, zezwolił on słuchaczom na spisywanie głoszonych przez siebie homilii. Jako że adresatami homilii byli w pierwszej kolejności słuchacze, ludzie o różnym poziomie wykształcenia, a nie czytelnicy i uczniowie aleksandryjskiej szkoły katechetycznej, styl homilii jest o wiele prostszy od stylu komentarzy, co nie oznacza, że porzucił on w nich interpretację alegoryczną. Poza nielicznymi fragmentami greckimi, homilie Orygenesa zachowały się w łacińskim przekładzie Rufina z Akwilei. Tłumacz starał się tak przekładać dzieła aleksandryjskiego teologa, by bronić jego dobrego imienia ${ }^{5}$.

\section{Analiza alegorycznej interpretacji historii Abrahama w wybranych homiliach o Księdze Rodzaju}

\subsection{Homilia III - Obrzezanie Abrahama}

O tym, że homilia III jest początkiem pewnej nowej całości, może świadczyć fakt, że nie rozpoczyna się ona od analizy czy interpretacji konkretnej perykopy biblijnej, lecz od namysłu natury metodologicznej. Orygenes porusza tu problem badawczy związany z antropomorfizmami biblijnymi. Aleksandryjski teolog chce zająć się tym zagadnieniem przed skomentowaniem treści będącej właściwym przedmiotem homilii III, jakim jest obrzezanie Abrahama.

By uzmysłowić słuchaczom, dlaczego i jak należy korzystać z interpretacji alegorycznej, Orygenes rozpoczyna homilię od analizy sformułowania pojawiającego się w Biblii: Bóg przemawia do ludzi $i^{6}$. Część żydów i chrześcijan interpretowała to na tyle dosłownie, że zaczynali oni przypisywać Bogu ludzki

3 Por. M. Simonetti, Między dosłownością a alegorią, s. 71-76.

4 Wersja łacińska dostępna w: W.A Baehrens (ed.), Homilien zum Hexateuch in Rufins Übersetzung. Tłumaczenie polskie dostępne w: Orygenes, Homilie o Księdze Rodzaju.

5 Por. R.E. Heine, Introduction, [w:] Origen, Homilies on Genesis and Exodus, s. 27-39.

6 Origenes, In Genesim III, 1. 
wygląd. Takie ujęcie wywołało jednak pogardliwą reakcję ze strony filozofów, którzy taki pogląd uważali za naiwny. Dla filozofów przypisanie mowy Bogu, który jest niewidzialny i niecielesny, oznaczało przypisywanie Mu również organów potrzebnych do mówienia. Taka krytyka niepokoiła chrześcijan.

Orygenes potwierdza opinię o Bogu, którą głoszą filozofowie: Bóg jest niecielesny, wszechmogący i niewidzialny ${ }^{7}$. Niemniej jednak, z troski o ludzi objawia on ludziom swoją wolę. Może to robić w sposób, który sprawi, że ludzie Go zrozumieją - musi więc niejako „zniżyć” swój sposób komunikowania do poziomu ludzi. Pedagogiczną metodę obrazowania, obecną w Starym Testamencie, w podobny sposób wyjaśniał Filon z Aleksandrii ${ }^{8}$. Odnosząc się do słów o gniewie Boga z Rdz 6, Filon tłumaczy w komentarzu Quod Deus immutabilis sit, że jest to rodzaj „użytecznego kłamstwa”, które jest potrzebne do zakomunikowania pewnych treści ludziom prostym i niewykształconym, do których przemawiają jedynie plastyczne, antropomorficzne opisy ${ }^{9}$.

Obecna w Biblii pedagogia dopuszcza sformułowania, które z jednej strony dają ludziom pojęcie o woli Bożej, choć z drugiej nie należy ich interpretować dosłownie, lecz alegorycznie. I tak słowa o „gniewie” czy „żalu” Boga nie oznaczają, że podlega on uczuciom, lecz są sposobem zakomunikowania ludziom, że dokonują złych czynów. Tu znów Orygenes wydaje się inspirować Filonem, który porównywał Mojżesza do lekarza, który za wszelką cenę ma leczyć ludzi z ich wad - czasami jedynym lekarstwem na złe uczynki ludzi prostych jest właśnie zastosowanie antropomorfizmów ${ }^{10}$. Podobnie ma się według Orygenesa sprawa z „głosem Boga”. Głos ten nie jest wytworzony przez język, wywołujący drgania powietrza, lecz jest kierowany działaniem niebiańskiej woli ${ }^{11}$. Bóg przemawiał do proroków, patriarchów poprzez oświecenie ich umysłu poprzez Swego Ducha. Słowo Boże jest więc rozumiane na sposób duchowy, nie ludzko-mechaniczny.

Sprawa obrzezania była w społeczności żydowskiej żyjącej w świecie grecko-rzymskim uważana za problematyczną. $Z$ jednej strony był to nakaz starotestamentalny, skierowany do Abrahama i jego potomstwa, a z drugiej strony, w świecie grecko-rzymskim patrzono na to negatywnie, jako na okaleczenie. Stąd też część Żydów już w epoce hellenistycznej starała się zakryć swoje obrzezanie $^{12}$. Do tej praktyki na kartach Nowego Testamentu odnosi się również

7 Ibidem III, 2.

8 Por. D. Mrugalski, Bóg niezdolny do gniewu, s. 282-290.

9 Filon, Quod Deus immutabilis sit, 61-64.

10 Ibidem 67-68.

11 Origenes, In Genesim III, 2.

$121 \mathrm{Mch}, 1,15$. 
św. Paweł z Tarsu. Odrzuca on konieczność obrzezania wskazując, że właściwe rozumienie obrzezania to Obrzezanie serca, duchowe, a nie wedtug litery

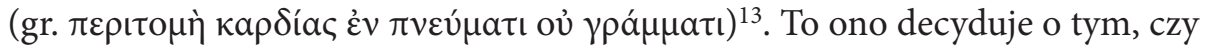
ktoś jest prawdziwym Żydem, czyli chrześcijaninem. W egzegezie wczesnochrześcijańskiej spotykamy radykalne odrzucenie nakazu obrzezania czego dowodem może być pochodzący z II wieku List Barnaby. Autor listu, choć widzi wartość duchowego obrzezania „w sercu”, to jednak odrzuca wartość obrzezania napletka, wskazując na to, że nawet pogańscy Egipcjanie dokonywali takich obrzędów. Objaśniając historię Abrahama, zinterpretował on numerologicznie liczbę obrzezanych sług jako imię i krzyż Chrystusa Co więcej, według autora obrzezanie napletka było czymś niewłaściwym nawet w epoce Starego Testamentu - to „zły anioł” nakłaniał do tego Izraelitów ${ }^{14}$.

Orygenes, powołując się na listy św. Pawła, konkluduje, że obrzezanie można rozumieć dwojako. $\mathrm{Z}$ jednej strony istnieje obrzezanie na ciele, a $\mathrm{z}$ drugiej obrzezanie $w$ sercu. To pierwsze, będące nakazem starotestamentalnego prawa rytualnego, było zapowiedzią „przyszłej prawdy”, czyli udoskonalonego prawa Nowego Testamentu. Orygenes w toku argumentacji dokonuje ciekawego zabiegu retorycznego - przywołuje bowiem argumenty wyimaginowanego polemisty-żyda, by następnie zbić jego argumentację. Według przeciwników Orygenesa nie można interpretować alegorycznie nakazu obrzezania jako obrzezania serca, gdyż już prorocy Starego Testamentu wprowadzili obrzezanie $w$ ciele i obrzezanie $w$ sercu. Tak więc skoro już w Starym Testamencie istniało obrzezaniu $w$ sercu, to nie można nakazów obrzędowych Starego Przymierza interpretować w ten sposób, by znieść konieczność poddania się zabiegowi obrzezania napletka przez mężczyzn ${ }^{15}$.

W odpowiedzi na tę trudność Orygenes zarysowuje szeroki sposób rozumienia obrzezania, nieograniczający się wyłącznie do obrzezania napletka ${ }^{16}$. Obrzezanie uszu to niesłuchanie oszczerstw, złorzeczeń, bluźnierstw, kłamstw i lubieżnych utworów literackich; obrzezanie warg to niechęć do wygłaszania kłamstw, błędów, bluźnierstw, lubieżności, niechęć do sporów; obrzezanie serca to brak złych myśli, czy to pożądliwych, czy to heretyckich ${ }^{17}$. Obrzezanie

\section{$13 \mathrm{Rz} 17,29$.}

14 List Barnaby 9. Tłumaczenie na język polski w: M. Starowieyski, Pierwsi świadkowie, s. $179-199$.

15 Jak lapidarnie wyraża to Orygenes: allegoriae non superest locus, ubi utraque species circumcisionis exigitur (In Genesim III, 5).

16 Origenes, In Genesim III, 5.

17 Serce występuje tu, zgodnie z myślą semicką, biblijną, nie tylko jako siedziba uczuć czy popędów, ale też życia intelektualnego, por. J.H. Walton., V.H. Matthews, M.W. Chavalas, Komentarz historyczno-kulturowy do Biblii Hebrajskiej, s. 183. 
napletka zaś (odnoszące się bezpośrednio do historii Abrahama) jest czystością seksualną. Przejawia się ona albo w stanie dziewiczym, albo w stanie małżeńskim, pod warunkiem, że mąż zbliża się tylko do swojej jedynej żony i nie przekracza prawa naturalnego, to znaczy akt seksualny jest otwarty na powoływanie nowego życia. Na przykładzie obrzezania widać, że interpretacja alegoryczna u Orygenesa ma charakter rozszerzający - do części ciała wymienionych przez autorów starotestamentalnych, dodaje on także inne części - zarówno kończyny (ręce i nogi), jak i zmysły (wzrok, smak, węch). Chce on dać do zrozumienia czytelnikom, że w alegorycznym rozumieniu tego określenia, cały człowiek powinien być obrzezany, to znaczy wypełniać Prawo Boże i naturalne (działanie zgodne $\mathrm{z}$ funkcjami ciała), a także być wolnym od wszelkich nieuporządkowanych pragnień, myśli i czynów. Mamy więc do czynienia z interpretacją alegoryczną o wyraźnie etycznym celu. Orygenes wyraźnie krytykuje dosłowne odczytanie fragmentów Starego Przymierza nakazujących obrzezanie, nakaz ten nazywa „szpetnym, haniebnym i obrzydliwym” (łac. turpem, foedam, deformem $)^{18}$.

Zakończenie homilii zawiera wyraźny akcent chrystologiczny. Nakaz obrzezania, będący integralną częścią zawarcia przymierza Boga z Abrahamem, jest odczytywany nie tylko jako pewna alegoria etyczna, lecz także jako zapowiedź, prefiguracja Nowego Przymierza. Według tego rozumienia, obrzezanie należy interpretować typicznie (obrzezanie starotestamentalne jako antytyp, oddanie ciała na służbę Chrystusowi jako typ).

\subsection{Homilia IV - Na temat zapisu: Bóg ukazał się Abrahamowi}

Tematem IV homilii jest fragment Rdz 18, w którym Bóg i dwóch aniołów pod postaciami mężczyzn przychodzi do Abrahama. Rozmawiają oni z Abrahamem i Sarą, zapowiadają też karę dla Sodomy. Obraz ten, z oczywistych względów, jest pełen antropomorfizmów i opisów zdarzeń, które na pierwszy rzut oka mają niewiele wspólnego z poznaniem Boga.

W przeciwieństwie do poprzedniej homilii, Orygenes nie rozpoczyna homilii IV wstępem metodologicznym, lecz koncentruje się głównie na punktowym niwelowaniu antropomorfizmów, zarówno w sformułowaniach użytych przed autora biblijnego, jak i w poszczególnych zdarzeniach. I tak, Bóg ze swoimi aniołami przyszedł do Lota w nocy a do Abrahama w południe, gdyż Abraham potrafił przyjąć blask światłości, natomiast Lot nie. Autor homilii stara się wykorzystać pewną grę słów, która występuje w Septuagincie: podpłomyki,

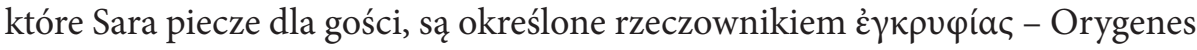

18 Origenes, In Genesim III, 6. 
łączy to z przymiotnikiem é $ү \kappa \rho u ́ \varphi ı$ (ukryty, tajemniczy), co ma naprowadzać czytelnika na pewien ukryty, mistyczny sens tekstu ${ }^{19}$. Tego typu zabiegi stosowali także inni aleksandryjscy myśliciele korzystający z interpretacji alegorycznej: Filon z Aleksandrii, alegorycznie interpretując postaci cherubinów,

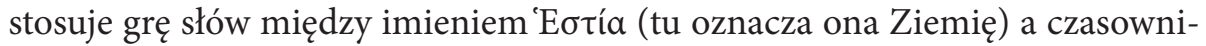

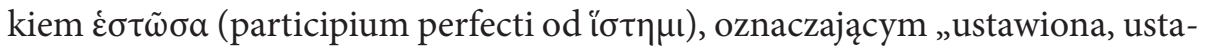
nowiona, stojąca" ${ }^{20}$.

Następnie Orygenes tłumaczy frazę „stanęli nad nim” (scil. nad Abrahamem) jako poddanie się woli Bożej przez Abrahama ${ }^{21}$. Utuczone ciele jest dla niego zapowiedzią śmierci Chrystusa. Alegorycznej interpretacji podlega też fakt, że Abraham podczas wizyty stał pod dębem Mamre - Orygenes uważa, że sam ten fakt, odczytany dosłownie, nie wnosi niczego wartościowego do przeżywania wiary. Dlatego też, odnosząc się do etymologii nazwy Mamre (widzenie, przenikliwość), tłumaczy, że Abraham miał kontakt z Bogiem ze względu na przenikliwość i czyste serce.

Orygenes bardzo ciekawie alegoryzuje postawę Sary, wykazując przy tym spore wpływy wcześniejszej judeohellenistycznej i chrześcijańskiej interpretacji alegorycznej. Filon wielokrotnie na kartach swoich utworów odnosił się do postaci żon Abrahama, interpretując je alegorycznie. Zwięzłym przykładem tej interpretacji jest fragment utworu De Cherubim ${ }^{22}$. Hagar została tam zinter-

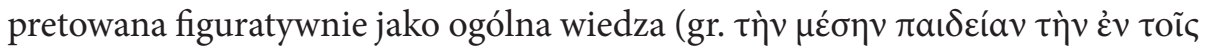
$\dot{\varepsilon} \gamma \kappa v \kappa \lambda$ íoıৎ). Powinna ona służyć celom wyższym, tzn. cnocie, którą oznacza tu Sara. Rozważania Filona należy rozumieć w ten sposób, że przyszły mędrzec (Abraham), będąc jeszcze na etapie badania zjawisk naturalnych (Abram), zaznajamia się z ogólnym wykształceniem (Hagar), choć ma ono jedynie wartość pomocniczą, względną, bo prawdziwym celem jest osiągnięcie cnoty (Sara), która dopiero po pewnym czasie staje się płodna ${ }^{23}$. Sama Hagar jest zdolna jedynie do spłodzenia sofisty, to znaczy Izmaela. W innym kierunku zmierza interpretacja Sary i Hagar, dokonana przez św. Pawła. Ta druga jest dla niego alegorią przymierza zawartego z Narodem Izraela na Górze Synaj, które ma swoją kontynuację na Wzgórzu Świątynnym w Jerozolimie (Stare Przymierze,

19 Ibidem IV, 1.

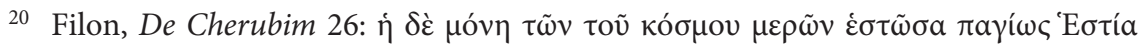

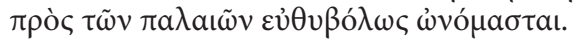

21 Origenes, In Genesim IV, 2.

22 Filon, De Cherubim 3-9, a także De congressu eruditionis gratia 23-24.

23 Podobną interpretację przedstawia Klemens z Aleksandrii, powołując się zresztą na Filona, por. Stromata I, 30,1-31,2. Szczegółowe omówienie oferuje A. van den Hoek, Clement of Alexandria and His Use of Philo in the Stromateis, s. 23-47. 
tkwiące w niewoli), natomiast Sara wyobraża chrześcijan, zrodzonych ku wolności, których ojczyzną jest górne Jeruzalem ${ }^{24}$.

W warstwie dosłownej tekstu biblijnego, gdy Bóg obwieszczał, że Sara urodzi syna, stała ona za Abrahamem. Orygenes przeprowadza w IV homilii pewną dwustopniową interpretację alegoryczną tego zdarzenia. Na początku stara się wydobyć sens etyczny, wskazując, że żona powinna stać za mężem, to znaczy być mu posłuszna ${ }^{25}$. Później jednak dokonuje interpretacji wyższego rzędu, odczytując postaci Abrahama i Sary jako alegorie odnoszące się do antropologii - Abraham jest tu alegorią rozumu, Sara natomiast alegorią ciała. W bardzo podobny sposób opozycję mężczyzna-kobieta rozumiał Filon, choć zobrazował to postaciami Adama i Ewy, gdzie Adam jest interpretowany

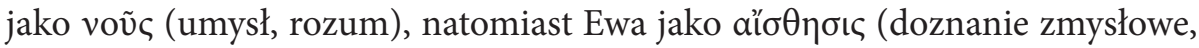
zmysł) ${ }^{26}$.

Z tej interpretacji Abrahama i Sary Orygenes wyciąga wniosek o charakterze etycznym - człowiek powinien żyć tak, by rozum podporządkowywał sobie ciało wraz z jego popędami. Należy w tym miejscu zadać pytanie, czy interpretując postaci biblijne jako składniki psychofizycznej natury człowieka, Orygenes nie znosi sensu dosłownego biblijnej historii. Odnosząc się do wieku Abrahama i Sary, twierdzi, że starość należy rozumieć nie jako podeszły wiek, lecz jako dojrzałość. W ten sam sposób młodość i starość interpretuje Filon z Aleksandrii w utworze De sobrietate, gdzie za pomocą tego rodzaju interpretacji alegorycznej tłumaczy między innymi pewną niekonsekwencję, związaną $\mathrm{z}$ wiekiem syna Hagar, Izmaela - miał on mieć ponad 15 lat, w czasie, gdy wypędzana matka wzięła go na swoje barki i odeszła od Abrahama ${ }^{27}$.

Dłuższy fragment homilii Orygenes poświęca następującemu wersetowi Księgi Rodzaju: Rozlega się krzyk na Sodomę i Gomorę, a grzechy ich są bardzo wielkie. Zszedłem więc, aby zobaczyć, czy postępuja zgodnie z ich wołaniem, które doszło do mnie; a jeśli nie, chcę się dowiedziećc ${ }^{2}$. Fragment ten, na płaszczyźnie dosłownej, przysparza przynajmniej dwóch problemów interpretacyjnych. $Z$ jednej strony jest tu mowa o zejściu czy zstąpieniu Boga, co na poziomie dosłownym sugeruje, że Bóg zajmuje określone miejsce w przestrzeni i przemieszcza się, co wydaje się być sprzeczne z jego niecielesnością i niezmiennością. Z drugiej strony ostatnie słowa wersetu zdają się sugerować, że Bóg nie

$24 \mathrm{Ga} 4,21-31$.

25 Origenes, In Genesim IV, 4.

26 Filon, De Cherubim 57-64 oraz Legum Allegoriae 2, 49.

27 Idem, De sobrietate 6-9. Niezgodność tę współczesna biblistyka wyjaśnia przez hipotezę kilku źródeł powstania Tory, por. G. von Rad, Genesis. A commentary, s. 230-235.

$28 \mathrm{Rdz} 18,21$. Tłumaczenie $\mathrm{Rdz}$ podane za tłumaczeniem homilii Orygenesa. 
jest wszechwiedzący. Orygenes odrzuca obie te dosłowne interpretacje, drugą z nich nazywając wręcz heretycką. Po pierwsze, nie należy rozumieć zstępowania jako zmiany miejsca położenia, lecz jako chęć pochylenia się nad troskami ludzi, pragnienie opieki nad stworzeniem ze strony Boga. Podobnym problemem zajmowali się wcześniejsi interpretatorzy Tory, jak chociażby Arystobul. Interpretując zstąpienie Boga na górę Synaj, wyraźnie zaznacza, że Bóg jest wszędzie, więc, w przeciwieństwie do człowieka, nie może zajmować określonego miejsca w przestrzeni ${ }^{29}$.

$\mathrm{W}$ rozumieniu chrystologicznym, owo zstąpienie Boga jest prefiguracją Wcielenia Chrystusa, które także nastąpiło ze względu na pomoc Boga dla człowieka. Odnośnie do rzekomej niewiedzy Boga, Orygenes przyznaje, że Bóg nie zna grzechu. Bóg nie zna grzeszników, nie zna tych, którzy sa Mu obcy ${ }^{30}$. Nie oznacza to jednak, że przypisuje Bogu niewiedzę - to byłoby bluźnierstwo. Owa nieznajomość grzechu i grzeszników w interpretacji Orygenesa oznacza, że zarówno grzech, jak i grzesznicy, ze względu na swoje grzechy, nie są godni tego, by Bóg na nich spojrzał, by ich poznał. Kładąc akcent na konieczność sprawiedliwego życia, Orygenes oddala zarzuty dotyczące antropomorfizmu Starego Testamentu.

\subsection{Homilia VI - Jak Abimelech chciał Sarę pojąć za żonę}

Homilia VI odnosi się do historii z Rdz 20. Jest ona bliźniaczo podobna do historii o pobycie Abrahama w Egipcie ( $\mathrm{Rdz} 12$ ) oraz do historii pobytu Izaaka i Rebeki w Gerarze ( $\mathrm{Rdz} 26$ ). Jak zauważa Orygenes, na poziomie dosłownym historia ta nie wytrzymuje krytyki przynajmniej z kilku powodów. Po pierwsze, Abraham namawia tu do nieszczerości. Po drugie, ze strachu o swoje życie „udostępnia” swoją żonę Abimelekowi. Po trzecie, dlaczego Bóg dotknął chorobą nieświadomego niczego Abimeleka?

Orygenes dosłownie rozumianą historię nazywa pogardliwie głupimi, $\dot{z} y$ dowskimi baśniami (łac. ineptis et Iudaicis fabulis) ${ }^{31}$, a czytelników, którzy chcą pozostać przy sensie dosłownym, odsyła do żydów - chrześcijanie bowiem nie mogą zatrzymywać się na sensie literalnym Pisma, co wynika chociażby z egzegezy obecnej w listach św. Pawła. Aby obronić narrację o patriarchach przed zarzutem nieobyczajności, rozpoczyna od alegorycznej interpretacji postaci Sary.

29 Arystobul, Testimonia i fragmenty, s. 30-33. Warto zaznaczyć tu, że interpretacja alegoryczna u Arystobula miała dość ograniczony, punktowy charakter, por. T. Bednarek, Wstęp do przekładu testimoniów i fragmentów Arystobula, s. 19-20.

30 Origenes, In Genesim IV, 6.

31 Ibidem VI, 3. 
Korzystając z etymologii tego hebrajskiego imienia (oznacza ono władczynię, przywódczynię), wnioskuje, że Sarę należy alegorycznie rozumieć jako cnotę, co jest prawdopodobnym śladem inspiracji filońskiej - według Filona Sara,

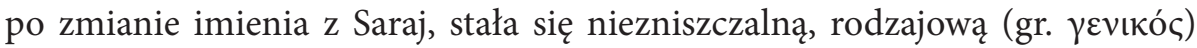
cnotą $^{32}$. Ten sposób tłumaczenia Sary był swego rodzaju toposem starożytnej chrześcijańskiej interpretacji alegorycznej, o czym świadczą pisma późniejszych autorów, jak choćby działającego w IV wieku w Aleksandrii Didyma Ślepego $^{33}$.

Abraham, alegorycznie interpretowany jako mędrzec, jest mężem Sary-cnoty, to znaczy powinien postępować zgodnie z jej radami - w ten sposób Orygenes tłumaczy słowa Boga, skierowane do Abrahama: Cokolwiek powie ci Sara, słuchaj jej głosu ${ }^{34}$. Na poziomie dosłownym są one nie tyle niezrozumiałe, co wręcz błędne - w myśl tego, o czym Orygenes pisał w homilii IV, to kobieta powinna słuchać męża. Jeśli jednak całkowicie zniesiemy, unieważnimy sens dosłowny (a wydaje się, że właśnie to czyni Orygenes), to sprzeczność znika.

Jak zatem rozumieć „podzielenie się” Sarą z Abimelekiem? Orygenes odpowiada na to pytanie przez pewną wizję historyczno-teologiczną, opisaną rzecz jasna za pomocą interpretacji alegorycznej. Jak już wspomniano, Sara jest tu rozumiana jako cnota, zaś Abraham jako mędrzec, który na drodze do doskonałości pragnie mieć cnotę tylko dla siebie. Gdy jednak osiągnie cnotę, może dzielić się nią z innymi, nauczać jej. W tej wizji Abimelek, w przeciwieństwie do faraona z Rdz 12, mającego złe zamiary, jest rozumiany jako filozof, który choć nie miał dostępu do Objawienia Bożego, to jednak z czystym sercem poszukuje cnoty. Jako że jest to jeszcze czas Starego Przymierza (tu Orygenes włącza drugi, chrystologiczny poziom interpretacji alegorycznej), nie może on jeszcze osiągnąć prawdziwej cnoty, musi zadowolić się własnymi żonami, interpretowanymi jako filozofia naturalna, i niewolnicami, rozumianymi jako różnorakie poglądy dialektyczne różnych szkót filozoficznych (łac. diversa et varia pro qualitate sectarum commenta dialecticae) ${ }^{35}$. Kiedy nadejdzie Nowe Przymierze, cnota będzie dostępna także dla pogan, a uzdrowiona filozofia naturalna i dialektyka urodza synów Kościoła.

32 Filon, De Cherubim 7, De mutatione nominum 77-80, De congressu eruditionis gratia 1-10.

33 Didymus Caecus, In Genesim 226-227 (za wydaniem Sources Chrétiennes).

$34 \mathrm{Rdz} 21,12$.

35 Origenes, In Genesim VI, 3. 


\section{Podsumowanie}

Interpretacja alegoryczna w homiliach o Księdze Rodzaju Orygenesa jest jednym z głównych narzędzi hermeneutyki biblijnej. Sama alegoria jest rozpatrywana w kategoriach poznawczych, Orygenes nie zawęża jej jedynie do teorii literatury czy retoryki. Najważniejszym świadectwem takiego podejścia do zagadnienia interpretacji alegorycznej jest metodologiczny wstęp do homilii III. Orygenes wskazuje tam, że choć dosłownie rozumiane antropomorfizmy były na pewnym etapie rozwoju umysłowego niezbędnym narzędziem pedagogicznym, to jednak, by zrozumieć je właściwie, muszą być one interpretowane alegorycznie.

Odnośnie do funkcji interpretacji alegorycznej w homiliach, to na pierwszy plan wybija się funkcja apologetyczna - interpretacja alegoryczna jest tu narzędziem do niwelowania czy wręcz znoszenia antropomorfizmów, istniejących w warstwie dosłownej tekstu biblijnego. Dzięki temu z jednej strony autor homilii usuwa to, co jest nie do zaakceptowania w świecie grecko-rzymskim, a z drugiej strony umożliwia legitymizację tekstu sakralnego ${ }^{36}$. Jako że interpretacja alegoryczna w homiliach Orygenesa ma niejako tworzyć pomost między światem hebrajskim a światem grecko-rzymskim, właściwe wydaje się też wspomnienie o innej roli interpretacji alegorycznej, jaką jest łączenie odmiennych przekazów kulturowych.

Podejmując temat interpretacji alegorycznej historii Abrahama w ujęciu Orygenesa, warto zaznaczyć, że nie był on pierwszym teologiem i filozofem, który mierzył się z tym tematem. Nie jest to niczym dziwnym, zważywszy na fakt, że Abraham jest ojcem narodu żydowskiego, ważnym dla wyznawców wszystkich religii, nomen omen, abrahamicznych. Na podstawie analizowanych homilii można stwierdzić zakorzenienie Orygenesa w tradycji aleksandryjskiej, szczególnie widoczne są nawiązania do interpretacji alegorycznej u Filona.

Jeżeli chodzi o treści, które autor homilii chciał wydobyć z tekstu za pomocą interpretacji alegorycznej, to w tekście odnajdujemy interpretację alegoryczną o charakterze etycznym, chrystologicznym, psychicznym i antropologicznym ${ }^{37}$.

36 Por. M. Domaradzki, Filozofia antyczna wobec problemu interpretacji, s. 106.

37 Co prawda, istnieją tendencje ku temu, by oddzielać interpretację alegoryczną od interpretacji niedosłownej zorientowanej na zagadnienia etyczne (tropologia) czy na zagadnienie zapowiadania Nowego Testamentu przez Stary (typologia), niemniej jednak, jak słusznie zauważa M. Domaradzki (por. M. Domaradzki, Między alegoria a typologia, s. 19-20), rozróżnienia te mają charakter późniejszy, wtórny. Ponadto problematyczne jest 
Zdarza się, że konkretny wers Orygenes interpretuje na wielu poziomach, na przykład na poziomie etycznym i chrystologicznym jednocześnie.

Interpretacja Orygenesa zaprezentowana w homiliach nosi wiele znamion interpretacji alegorycznej ${ }^{38}$. Interpretacja alegoryczna jest tu szeroko stosowana, znaczenie dosłowne Pisma schodzi na plan dalszy, a czasem jest wręcz znoszone, unieważniane przez interpretację alegoryczną. W związku z tym opinię o mniejszej alegoryczności homilii Orygenesa w porównaniu z jego komentarzami biblijnymi należy przede wszystkim wiązać ze zmianą adresata $\mathrm{z}$ czytelnika na słuchacza, a nie ze zmianą postawy filozoficzno-hermeneutycznej.

\section{Bibliografia}

Arystobul, Testimonia i fragmenty, tłum. T. Bednarek, Studia Antyczne i mediewistyczne 51 (2018), s. 23-40.

Bednarek T., Wstęp do przekładu testimoniów i fragmentów Arystobula, Studia Antyczne i Mediewistyczne 51 (2018), s. 17-21.

Baehrens W.A. (ed.), Homilien zum Hexateuch in Rufins Übersetzung. Erster Teil. Die Homilien zu Genesis, Exodus und Leviticus, [w:] Baehrens W.A. (ed.), Origenes Werke. Sechster Band, Leipzig 1920.

Bardski K. Intencja tekstu a sens ponaddosłowny. Uwagi na marginesie artykułu ks. Piotra Klimka pt. Powołanie Jeremiasza (Jr 1,4-10) w „Pierwszej Homilii o Księdze Jeremiasza“ Orygenesa, Warszawskie Studia Teologiczne 17 (2004), s. 42-44.

Didyme l'Aveugle, Sur la Genesè, Tome II, Introduction, Edition, Traduction et Notes par Pierre Nautin, Paris 1978.

Domaradzki M., Filozofia antyczna wobec problemu interpretacji. Rozwój alegorezy od przedsokratyków do Arystotelesa, Poznań 2013.

Domaradzki M., Między alegoria a typologia. Uwagi o hermeneutyce Orygenesa, Przegląd Religioznawczy 239/1 (2011), s. 17-27.

Filon Aleksandryjski, Pisma. Tom I, tłum. L. Joachimowicz, Warszawa 1986.

Filon Aleksandryjski, Pisma. Tom II, tłum. S. Kalinkowski, Kraków 1994.

Jacobsen A.-Ch., Allegorical Interpretation of Geography in Origen's Homilies on the Book of Joshua, Religion and Theology 17 (2010), s. 289-301.

precyzyjne oddzielenie tych metod interpretacji, w związku z czym bezpieczniej jest mówić o pewnych typach interpretacji alegorycznej.

38 Wykorzystuję tutaj ustalenia poczynione przez M. Domaradzkiego, który odróżnia egzegezę od interpretacji alegorycznej, por. M. Domaradzki, Filozofia antyczna wobec problemu interpretacji, s. 25-27. Nieco podobnie, choć za pomocą terminów „hiperallegoryści” i „allegoryści umiarkowani” różne rodzaje działalności interpretacyjnej odróżniał od siebie Tadeusz Zieliński, por. T. Zieliński Hellenizm a Judaizm. Tom II, s. 99-106. 
Kierkegaard S., Bojaźń i drżenie. Choroba na śmierć, tłum. J. Iwaszkiewicz, Warszawa 1969.

Klimek P., Powołanie Jeremiasza (Jr 1,4-10) w „Pierwszej homilii o Księdze Jeremiasza” Orygenesa, Warszawskie Studia Teologiczne 17 (2004), s. 31-41.

Łuczak P., Funkcje symbolicznej interpretacji Pentateuchu w homiliach Orygenesa, Scripta Minora Selecta 1 (1996), s. 45-82.

Mrugalski D. Bóg niezdolny do gniewu. Obrona apathei Boga w teologii aleksandryjskiej: Filon, Klemens i Orygenes, Verbum Vitae 33 (2018), s. 279-314.

Origen, Homilies on Genesis and Exodus, translated by Ronald E. Heine, Washington D.C. 2002.

Orygenes, Homilie o Księdze Rodzaju. Homilie o Księdze Wyjścia, tłum. S. Kalinkowski, wprowadzenie H. Pietras SJ, Kraków 2012.

Philo, Allegorical Interpretation of Genesis II and III, translated by F.H. Colson, G.H. Whitaker, [w:] Philo, Works. Volume I, Cambridge 1929.

Philo, On Mating with the Preliminary Studies, translated by F.H. Colson, G.H. Whitaker, [w:] Philo, Works. Volume IV, Cambridge 1932.

Philo, On the Change of Names, translated by F.H. Colson, G.H. Whitaker, [w:] Philo, Works. Volume V, Cambridge 1934.

Philo, On the Cherubim, the Flaming Sword, and Cain, translated by F.H. Colson, G.H. Whitaker, [w:] Philo, Works. Volume II, Cambridge 1929.

Pismo Święte Starego i Nowego Testamentu. Biblia Tysiąclecia. Wydanie IV, Poznań 1983. Rad G. v., Genesis. A Commentary. Revised Edition, Philadelphia 1973.

Simonetti M., Między dosłownościa a alegorią. Przyczynek do historii egzegezy patrystycznej, Kraków 2000.

Słomka J., Oczyszczenie z grzechu w homiliach Orygenesa o Księdze Kapłańskiej, Śląskie Studia Historyczno-Teologiczne 38 (2005), s. 337-353.

Słomka J., Orygenes o kapłaństwie i Eucharystii w homiliach o Księdze Kapłańskiej, Vox Patrum 44-45 (2003), s. 99-117.

Spyra M., Elementy teologii chrzcielnej w czwartej i piątej homilii Orygenesa do Ksiegi Jozuego, Śląskie Studia Historyczno-Teologiczne 19-20 (1986-1987), s. 41-64.

Starowieyski M. (ed.), Pierwsi Świadkowie: Pisma Ojców Apostolskich, tłum. A. Świderkówna, Kraków 2010.

van den Hoek A., Clement of Alexandria and His Use of Philo in the Stromateis: An Early Christian Reshaping of a Jewish Model, Leiden 1988.

Walton J.H., Matthews V.H., Chavalas M.W., Komentarz historyczno-kulturowy do Biblii Hebrajskiej, Warszawa 2005.

Zieliński T., Hellenizm a judaizm. Tom II, Warszawa 1927. 